\title{
EMOSI TAKUT DALAM HUJAN SUDAH TEDUH ZAHARAH NAWAWI
}

\section{FEARSOME EMOTIONS IN HUJAN SUDAH TEDUH BY ZAHARAH NAWAWI}

\author{
Nordiana Hamzah \& Azhar Wahid \\ Jabatan Bahasa Melayu dan Kesusasteraan \\ Fakulti Bahasa dan Komunikasi \\ Universiti Pendidikan Sultan Idris, Tanjong Malim, Perak \\ diana.azmi@fbk.upsi.edu.my,azhar@fbk.upsi.edu.my
}

\begin{abstract}
ABSTRAK
Makalah ini bertujuan untuk menganalisis emosi takut yang terdapat dalam novel. Emosi takut membawa maksud perasaan tidak rasional, berlebihan dan ketakutan yang berulang-ulang dalam satu-satu situasi. Objektif kajian adalah untuk menganalisis emosi takut yang dialami oleh wanita Melayu yang terdapat dalam novel terpilih dan menjelaskan tindakan yang dilakukan oleh mereka apabila berasa takut. Metodologi yang digunakan ialah pendekatan kualitatif dengan menggunakan kajian kepustakaan dan kajian teks. Instrumen yang digunakan ialah senarai semak analisis teks dengan menggunakan kerangka teori emosi adaptasi dari kajian Nordiana Hamzah (2014). Sampel data ialah teks Zaharah Nawawi iaitu teks Hujan Sudah Teduh (2004). Dapatan kajian menunjukkan emosi protagonis wanita Melayu yang mulanya berasa takut tetapi akhirnya, mereka akan menukar emosi takut tersebut kepada emosi untuk melawan yang dikenali sebagai emosi tenaga. Hal ini dapat dianalisis melalui teknik penulisan, watak, gaya bahasa dan latar yang diperikan oleh pengarang bagi menggambarkan emosi takut. Signifikan kajian ialah, emosi wanita Melayu ialah paradoks kerana dalam keadaan takut, sebenarnya mereka penuh bertenaga sesuai dengan fitrah wanita yang nampaknya polos namun hati waja bagaikan besi.
\end{abstract}

Kata kunci: Emosi, wanita Melayu, emosi takut.

\begin{abstract}
This paper aims to analyze the fearsome emotions found in the novel. Fearsome emotions are meant to be irrational, excessive and repetitive fears in a situation. The objective of the study is to analyze the fearsome emotions experienced by the Malay women in the selected novel and to explain the actions taken by them when they were scared. The methodology used is a qualitative approach using literature study and text study. The instrument used is a text analysis checklist by using the theoretical framework adapted from Nordiana Hamzah (2014) study. The data for sample is from the Zaharah Nawawi text that is Hujan Sudah Teduh (2004) text. The findings show that the protagonist emotion of the Malay women who initially felt afraid but ultimately, they would change the fearsome to the emotions to fight which is known as emotional energy. This can be analyzed through writing, character, language and background techniques written by the author to illustrate the fearsome emotions. Significantly, the emotion of Malay women is a paradox because in fear, they are actually energetic in accordance with the nature of a woman who looks innocent but her heart is as an iron.
\end{abstract}

Keywords: Emotions, Malay women, fearsome emotions. 


\section{PENGENALAN}

Emosi takut membawa maksud perasaan tidak rasional, berlebihan dan ketakutan yang berulang dalam satu-satu situasi. Emosi takut membuat sel-sel di pusat emosi otak menghasilkan hormon yang membuat tubuh berwaspada, sentiasa dalam keadaan was-was dan bersedia untuk bertindak. Emosi takut mendorong otot-otot rangka besar seperti kaki dan tangan untuk bersedia bertindak. Di samping itu juga, emosi takut menimbulkan wajah pucat dan darah terasa dingin. Marc Grobe (2001: 4), pula menyatakan faedah emosi ketakutan menyebabkan individu tersebut sentiasa beringat dalam kehidupannya.

Emosi takut menurut Jadunath, ialah kegelisahan berlebihan yang berlaku di dalam minda. Di samping itu juga emosi takut ditakrifkan sebagai kekacauan yang berlaku di dalam minda yang dirangsang oleh objek yang dahsyat. Emosi takut ialah emosi dasar manakala kesan emosi takut merupakan emosi yang sementara (1986:196). Simptom emosi takut yang terjadi pada anggota badan antaranya anak mata dibesarkan, gerakan jantung menjadi bertambah laju, warna kulit menjadi pucat, pernafasan menjadi lebih pantas daripada normal, dan bulu roma menegak (ibid).

Umumnya, emosi takut terbahagi kepada beberapa kategori. Antaranya terdapat emosi takut kepada penerbangan, ketinggian, kehilangan, kesakitan, penolakan, kematian, dan takut kepada kegelapan. Namun, emosi takut harus wajar kepada situasi seperti takut akan mati dan takut kepada bahaya manakala emosi takut seperti takut kepada anjing, ataupun kegelapan ialah ketakutan yang terjadi akibat pengalaman yang traumatik (Adi W.Gunawan, 2006:74). Pengalaman yang traumatik menyebabkan seseorang menjadi fobia kepada sesuatu perkara.

Emosi takut dijadikan Allah mempunyai hikmah. Insan perlu perasaan takut sebagai salah satu cara untuk melindungi dirinya daripada terperangkap dalam situasi yang membahayakan (Jamilah Samian, 2012). Laluan emosi takut bermula daripada fahaman komunikasi yang berpunca daripada alam bawah sedar yang membawa mesej ke alam sedar. Kewajaran untuk menangani emosi takut adalah dengan kekuatan iman. Melalui keimanan, seseorang individu membina sikap mental positif dan seterusnya bersikap positif. Misalnya rasa takut bertukar berani, putus asa menjadi semangat, bimbang bertukar yakin, sedih bertukar tenang dan juga sifat-sifat yang lain (Afifi Ahmad, 2005:87).

\section{METODOLOGI}

Dalam penulisan novel, menurut Teori Rasa Fenomenologi setiap ekspresi sastera mempunyai korelatif objektif ataupun penentu tertentu (Sohaimi Abd Aziz, 1998:117). Korelatif objektif menjadi inti bagi penulisan pengarang menerusi garapan tema, plot, watak, latar, sudut pandangan, gaya bahasa, yang merupakan strategi teknik penulisan pengarang. Pembaca pula, menerusi emosi dan mindanya akan mengesan korelatif objektif yang dihidupkan oleh pengarang untuk membantu diri mereka berkomunikasi secara aktif melalui pembacaan dan penghayatan tentang korelatif yang dihidupkan dalam karya.

Menurut Bharata, Emosi takut sebagai satu ekspresi sastera yang terwujud disebabkan oleh bunyi yang mengerikan, melihat hantu, peperangan, memasuki rumah kosong yang di dalam hutan, dan menyinggung perasaan orang-orang atasan (dalam Sohaimi Abd Aziz,1998:117).Tambahan lagi, menurut Kuppusamy Bangalore, Emosi takut juga wujud apabila kehadiran binatang liar dan objek berbahaya (2008:21). Peter M. dan Johari pula menyatakan kematian merupakan Emosi takut yang tertinggi darjahnya (2006:97). Oleh itu, Emosi takut satu ekspresi sastera yang muncul dalam diri manusia.

Teori yang digunakan dalam analisis ialah teori yang diadaptasi daripada kajian Nordiana Hamzah (2014), yang menggabungkan dua buah teori iaitu Teori Rasa Fenomenologi (TRF) oleh Sohaimi Abdul Aziz dan Teori Psikoanalisis (TPF) yang dipelopori oleh Freud. Gabungan kedua-dua teori ini menjelaskan TRF bersifat dominan kerana keseluruhan teori ini digunakan dan TPF hanya melengkapkan TRF dalam analisis teks. Terdapat pengguguran konsep teori TPF iaitu aspek perkembangan psikoseksual. Justifikasi 
pengguguran disebabkan aspek ini tidak dibincangkan dalam menganalisis emosi takut wanita Melayu yang terdapat dalam teks. Oleh itu, kerangka teori yang akan digunakan dalam menganalisis ini dapat dirujuk melalui Rajah 1:

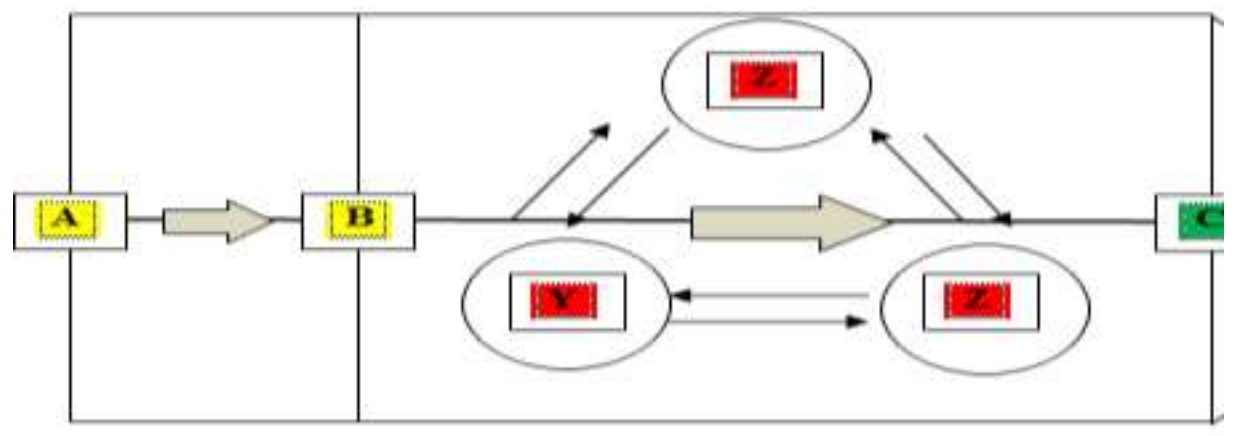

Rajah 1: Adaptasi daripada Nordiana Hamzah (2014). Penggabungan TRF dan Psikoanalisis Freud ( Batasan: Struktur Pemikiran Individu, Neurosis dan Mekanisme Helah Bela Diri).

Konsep-konsep yang terdapat dalam kerangka teori ini ialah:

\section{Teori Rasa Fenomenologi (TRF)}

Menurut Sohaimi Abdul Aziz (1998), TRF memberikan penumpuan kepada psikologi pembaca yang berasaskan penggunaan unsur psikologi iaitu emosi tetap. TRF menerima konsep peranan emosi dalam teori rasa- dhavani iaitu emosi tetap bukan sahaja terdapat pada pembaca dan karya, tetapi juga pada pengarang. Berdasarkan teori rasa dhavani, emosi tetap telah mengikat tiga komponen, iaitu pembaca, karya dan pengarang menjadi satu kesatuan yang dinamik. Emosi takut merupakan emosi tetap bagi pembaca dan pengarang namun dalam karya emosi takut akan dikenali sebagai Rasa Dahsyat. Jadual 1, menunjukkan perhubungan antara emosi tetap dengan ekspresi sastera.

Jadual 1: Perhubungan antara emosi tetap dengan ekspresi sastera.

\begin{tabular}{lll}
\hline PEMBACA & KARYA & PENGARANG \\
(Emosi Tetap $)$ & (Ekspresi Sastera ) & ( Emosi Tetap ) \\
\hline Takut (bhaya) & Dahsyat (bhayanaka) & Takut (bhaya) \\
\hline
\end{tabular}

Sumber Sohaimi Abdul Aziz, 1998.

\section{Korelatif Objektif}

Menurut Elliot (dalam Timo, M, 2010, p.70) korelatif objektif ialah penentu untuk mengesan emosi dalam karya. Hal ini boleh dirujuk menerusi petikan: 
The only way of expressing an emotion in the form of art is by finding an objective correlative:in other words, a set of objects, a situatin, a chain of events which shall be the formula of that particular emotion; such that when the external facts, which must terminate in sensory experience, are given, the emotion is immediately evoked.

Kajian ini menggunakan definisi korelatif objektif Sohaimi Abdul Aziz iaitu penentu yang digunakan oleh pengarang dalam mengarang. Sehubungan dengan itu, korelatif objektif digunakan sebagai penentu yang menghubungkan antara emosi tetap dengan ekspresi sastera.

Teori Psikoanalisis Freud (Batasan Struktur Pemikiran Individu, Neurosis dan Mekanisme Helah Bela Diri)

Struktur Pemikiran Individu mempunyi tiga sistem iaitu $i d$, ego dan superego. Ketiga-tiga sistem ini bukanlah suatu yang konkrit tetapi merupakan proses-proses yang berinteraksi antara satu sama lain bagi menghasilkan tingkah laku atau personaliti seseorang. Bagi Freud, $i d$ dianggap sebagai komponen biologi; ego sebagai komponen psikologi; dan superego pula sebagai komponen sosial dan nilai-nilai moral masyarakat. (Amir Awang, 1987, p. 3-5: ; Thomas, R. M. ,1996, p.108-111; Habibah Elias \& Noran Fauziah Yaakub, 1997; Hergenhahn, B. R., \& Olson, M.H., 2003; Rahil Mahyuddin et al. 2004; Suppiah et al. 2008).

Oleh itu, tahap perkembangan individu dipengaruhi oleh teori perkembangan personaliti yang terbentuk daripada tiga komponen, iaitu id, ego dan superego Id ialah bahagian personaliti yang mengandungi naluri sensual dan agresif. Id diwarisi sejak lahir lagi. Id beroperasi atas prinsip keseronokan. Ciri yang paling jelas tentang id ialah, tidak pernah matang dan hanya mahukan keseronokan.

Ego ialah personaliti manusia yang sebahagian berada pada aras bawah sedar dan sebahagian lagi berada pada aras sedar. Ego pula tidak wujud semasa lahir. Ego berkembang secara berperingkat dan bertindak atas rasional. Ego menjadi pengawal kehendak yang tidak dapat dipuaskan id.

Superego digunakan oleh Freud untuk menggambarkan penghayatan nilai-nilai moral dalam masyarakat. Superego diterapkan dalam diri seseorang sejak mereka dilahirkan sebagai pegangan moral dalam usaha menghalang kehendak id. Tugas utama superego adalah menahan desakan id dan memujuk ego supaya memilih matlamat yang bermoral dan realistik serta berusaha mencapai kejayaan.

Kesimpulannya dalam hubungan ini, id mendesak, ego mengatur dan superego memerhati dan menyelia gelagat id dan ego (ibid). Sewaktu proses penapisan dan pengawalan dalam memenuhi kehendakkehendak dan dorongan-dorongan id, sering terhasil perasaan risau atau kerisauan. Jika individu itu gagal bersublimasi maka neurosis telah terjadi iaitu konflik emosi dalam jiwa ( Mana, 2006. p.421).

Kerisauan ialah perkara penting dalam pembangunan teori Freud. Kerisauan ialah satu situasi tegang yang memotivasikan seseorang untuk bertingkah laku. Hal ini muncul akibat konflik antara id, ego dan superego. Oleh itu, apabila seseorang mengalami perasaan kerisauan ini mereka secara tindak balasnya akan melakukan helah bela diri. Helah bela diri, melindungi seseorang daripada tekanan perasaan dan kerisauan. Perkara ini reaksi normal terhadap tekanan perasaan yang dialami. Antara helah bela diri yang digunakan oleh seseorang itu dapat dirujuk dalam Jadual 2: 
Jadual 2: Mekanisme Helah Bela Diri

\begin{tabular}{|c|c|}
\hline Represi & $\begin{array}{l}\text { Benteng yang menyingkirkan semua pemikiran dan perasaan } \\
\text { yang mengancam dari alam sedar. }\end{array}$ \\
\hline Penyangkalan & $\begin{array}{l}\text { - Penyangkalan merupakan penafian atau penolakan akan adanya realiti yang } \\
\text { dilakukan secara sedar atau pra sedar. }\end{array}$ \\
\hline Pembentukan & $\begin{array}{l}\text { - Mempertahankan diri daripada sesuatu ancaman dengan memperlihatkan } \\
\text { reaksi yang bertentangan dengan bentuk ancaman itu. }\end{array}$ \\
\hline \multicolumn{2}{|l|}{ Reaksi } \\
\hline Projeksi & $\begin{array}{l}\text {-Mekanisme yang membalikkan desakan dan keinginan-keinginan yang } \\
\text { tidak dapat diterima oleh dirinya sendiri kepada orang lain. }\end{array}$ \\
\hline Penyaluran & $\begin{array}{l}\text {-Cara untuk mengawal kerisauan dengan melepaskan desakan-desakan itu } \\
\text { kepada sasaran lain yang lebih selamat. }\end{array}$ \\
\hline Rasionalisasi & $\begin{array}{l}\text {-Cara untuk memberi alasan-alasan atau sebab gagal, sebagai suatu usaha } \\
\text { untuk mempertahankan egonya. }\end{array}$ \\
\hline Sublimasi & $\begin{array}{l}\text {-Cara untuk melepaskan tenaga seks atau agresi ke jalan yang boleh diterima } \\
\text { oleh masyarakat. }\end{array}$ \\
\hline Regresi & $\begin{array}{l}\text {-Tindakan untuk menyorot kembali kepada peringkat perkembangan yang } \\
\text { lebih awal iaitu untuk mempunyai rasa selamat. }\end{array}$ \\
\hline Introjeksi & $\begin{array}{l}\text {-Suatu bentuk helah bela diri yang berlawanan dengan projeksi. Individu } \\
\text { membalikkan segala ciri yang tidak diingininya kepada individu yang lain, } \\
\text { sedangkan dalam introjeksi ia mengambil ciri-ciri atau nilai-nilai orang lain } \\
\text { untuk dijadikan ciri atau nilai dirinya. Ada antara ciri dan nilai baik dan ada } \\
\text { juga yang tidak baik. }\end{array}$ \\
\hline Pampasan & $\begin{array}{l}\text {-Suatu usaha untuk mengimbangkan sesuatu kelemahan yang ada pada diri } \\
\text { seseorang itu. }\end{array}$ \\
\hline Undoing & $\begin{array}{l}\text {-Tindakan untuk membaiki sesuatu yang telah rosak dengan harapan } \\
\text { mengurangkan rasa bersalah. }\end{array}$ \\
\hline
\end{tabular}

Sumber: Adaptasi daripada Nordiana Hamzah (2014).. Universiti Pendidikan Sultan Idris.

\section{PERBINCANGAN}

Emosi takut terakam dalam novel ZN seperti Hujan Sudah Teduh (HST). Laluan evolusi emosi takut dalam novel $H S T$ bermula pada titik praestetik. Pada peringkat ini persediaan awal bagi pembaca untuk menanggapi karya yang dibaca untuk persediaan mental. Aktiviti persediaan mental menjelaskan dan memantapkan lagi pemahaman pembaca tentang karya ZN. Korelatif objektif tentang penderaan telah dirakamkan dalam novel HST. Penderaan yang dipaparkan membabitkan penderaan kanak-kanak, penderaan fizikal, penderaan emosi, dan penderaan psikologi.

Penderaan ialah kanser dalam institusi kehidupan masyarakat yang telah wujud sejak zaman dahulu sehingga kini bahkan hal ini berlaku di pelosok dunia. Yang kroniknya, gejala penderaan telah menjadi semakin tenat dari hari ke hari. Dalam dunia media, sering kali dilaporkan dan menjadi hebahan aspek penderaan fizikal dan seksual. Namun aspek penderaan emosi tidak mendapat tarikan daripada pengamal media sekali gus masyarakat. Fakta ini harus diperbetulkan dan masyarakat sekeliling harus mengetahui bahawa penderaan emosi ini didapati kerap berlaku sama ada secara berasingan atau bersama-sama dengan jenis penderaan lain (Kasmini Kassim, 1998: Abstrak). Oleh itu, penderaan emosi adalah lebih parah berbanding dengan bentuk penderaan yang lain. 
Penderaan emosi menurut O’Hagan (2006:46), ialah suatu proses penderaan yang berterusan dan sentiasa berulang-ulang sama ada secara emosional terhadap perasaan mereka ataupun perilaku ekspresif ke atas mereka. Akibatnya, penderaan emosional telah menyebabkan halangan dalam proses perkembangan emosional. Hal ini memberikan kesan kepada seorang mangsa dera untuk memperoleh kemampuan bagi menyatakan dan mengekspresikan emosi yang berbeza dengan tepat. Akhirnya hal ini menyebabkan kesukaran untuk membantu mereka. Maka, terdapat kesan negatif pada perkembangan pendidikan mangsa dera, perkembangan sosial dan budaya, pembangunan psikologi dan kerjaya apabila dewasa.

Dalam novel HST, korelatif objektif penderaan menyumbang kepada Emosi takut yang menjadi pilihan ZN untuk mendedahkan pola perlakuan dan sikap negatif dalam kalangan masyarakat Melayu pada era tertentu (Amida Abdulhamid, 2005:Arkib). Minoriti pembaca tidak pernah mengalami peristiwa penderaan namun, hal ini tidak bermakna mereka tidak dapat menghayati korelatif objektif yang dihidupkan oleh pengarang kerana hal penderaan lumrah biasa dalam masyarakat hedonisme kini dan penceritaan penderaan banyak terakam dalam media sama ada media elektronik mahupun media bukan elektronik. Yang Zaiton telah mengalami penderaan lebih-lebih lagi penderaan emosi sejak zaman kanakkanak lagi. Hal ini dilihat menerusi petikan:

“Eii, Yang Cina ni banyak kutulah.”...Ada antara rakan Melah yang mengambil kayu pembaris menyelak rambut Yang, diikuti perbuatan memukul kutu yang melenting keluar apabila tempat persembunyiannya diganggu. "Eii, jijik! Jijik! Pengotor! Jangan dekat aku.”Jjah geli-geleman melarikan diri apabila Yang menghampirinya untuk mengelak daripada dikerumuni Melah dan rakan-rakannya Ijah menjauhkan diri. Melah dan gengnya juga takut berkawan dengan Yang. Yang berasa begitu hina.

(Zaharah Nawawi, 2004:63)

Daripada petikan ini, penderaan emosi Yang bermula dengan sikap rakan-rakan yang telah menunjukkan perasaan tidak senang untuk berkawan dengan Yang kerana pada rambut Yang mempunyai kutu yang banyak. Malah, Yang telah dipanggil dengan nama panggilan Yang Cina kerana Yang merupakan anak angkat berketurunan Cina. Latar masyarakat dalam novel ini menggambarkan masyarakat Melayu mempunyai hubungan yang tidak harmoni dengan masyarakat Cina disebabkan oleh masalah Bintang Tiga yang dianggotai oleh masyarakat Cina. Hal ini jelas dapat dilihat menerusi petikan:

Dendam lama orang kampong terhadap kaum Cina yang menjadi ahli Bintang Tiga, membunuh kejam orang Melayu, membakar rumah dan merampas harta serta ternakan masih marak membara. Hakikat yang sama sekali tidak boleh ditolak ialah Yang berketurunan Cina. Meskipun Yang tidak mengetahui apa yang berlaku sebelum dia mengenal dunia, namun sebagai pewaris keturunan yang dibenci itu, dia tetap mendapat tempias yang bukan kepalang peritnya.

(Zaharah Nawawi, 2004:207)

Namun, keluarga asal Yang bernasib baik kerana diterima oleh masyarakat Melayu di kampung tersebut kerana keluarga asal Yang bekerja sebagai penanam sayur. Walaupun Yang telah diserahkan kepada keluarga Melayu sejak kecil lagi, namun asal keturunannya masih lagi menjadi bahan ejekan. Yang telah dihina secara fizikal dan mental. Secara fizikalnya, rambut Yang telah diselak menggunakan kayu pembaris tanpa kebenaran Yang. Sebagai akibatnya emosi Yang dihina kerana rakan-rakan sekelas Yang telah menggelarnya sebagai penjijik dan pengotor. Yang telah dipulaukan oleh rakan-rakan. Sedangkan pada masa itu Yang baru berusia lima tahun. Pada usia sebegini telah menjadi mangsa penderaan emosi. Penderaan emosi dan keparahan emosi Yang dapat dilihat menerusi petikan: 
Yang mahu menangis. Hatinya amat sakit. Tubuh badan serta kepala juga sakit terkena ketukan pembaris, tetapi ditahan sekeras hati. Yang tahu, kalau dia menangis, mereka akan seronok. Dia tidak mahu menunjukkan kelemahan. Yang telan air matanya supaya tidak gugur di pipi.

\section{( Zaharah Nawawi, 2004:64)}

Merujuk petikan, Yang mengalami tekanan emosi akibat penderaan fizikal iaitu diketuk dengan pembaris di kepalanya. Akibatnya, Yang berasa mahu mengalirkan air matanya, namun Yang tahu jika dia menangis, hanya menyebabkan pendera berasa riang dan gembira. Oleh sebab itu, Yang mengambil keputusan untuk menahan air matanya. Hal ini berbeza dengan sikap kanak-kanak yang berumur lima tahun yang lain. Sudah pasti mereka akan menangis kerana dipukul kerana naluri kanak-kanak memang suka menangis. Tambahan lagi, hasil kajian sarjana telah menunjukkan iaitu pelakuan tidak sedar dalam diri dan rasa rendah diri kanak kanak mangsa dera telah dikaitkan kepada sikap agresif dan kesukaran dalam persekitaran (Cicchetti \& Toth, 1995:543). Bagi watak yang mempunyai pengalaman penderaan emosi akan menerbitkan perasaan rendah diri dan mempunyai kemampuan bersosial yang rendah. Kajian ini bertepatan dengan peristiwa yang menimpa Yang. Yang menjadi seorang kanak-kanak yang mempunyai rasa rendah diri dan tidak mempunyai kawan dan akhirnya akan bersikap agresif kepada persekitarannya.

Dalam kajian ini juga, sewaktu peringkat pengkonkritan estetik, amat mementingkan aspek estetik intertekstual, aspek evolusi emosi dalaman watak juga memainkan peranan yang penting untuk melihat emosi dalaman watak yang memberikan tindak balas kepada luaran untuk menghasilkan tingkah laku bagi menunjukkan emosi yang ada dalam jiwa. Perubahan tingkah laku watak digambarkan melalui mekanisme helah bela diri watak. Maka, analisis penggunaan teori Freud dalam aspek struktur pemikiran minda manusia memainkan peranan penting dalam menanggapi struktur pemikiran Yang Zaiton dalam menelusuri evolusi emosi takut dalam sastera yang menjelmakan Emosi takut. Analisis penelusuran dikaji untuk melihat emosi watak Yang dalam karya yang berevolusi. Dalam Emosi takut ini, diperlihatkan sikap Yang pada zaman kanak-kanak yang suka membatukan diri sewaktu didera. Emosi takut Yang Zaiton menimbulkan pelbagai tingkah laku seperti fobia dan histeria, lantas ke alam neurotik dan aspek ini semua mengarah kepada pembentukan personaliti individu (Mana Sikana, 2000:3).

Emosi dalaman Yang Zaiton berkecamuk dalam memikirkan tindakan yang akan dilakukan kerana didera. Pada mulanya Yang Zaiton menyimpan emosi dalam jiwanya (sublimasi) namun, apabila dirangsang oleh Isa untuk membalas dendam, Yang Zaiton telah membalas segala pelakuan rakan-rakan sekelasnya dengan membaling apa-apa sahaja benda yang boleh dibaling kepada mereka. Oleh itu, emosi yang diterbitkan oleh Yang Zaiton ini dikenali sebagai neurosis iaitu tekanan emosi dalam jiwa bawah sedar. Neurosis menurut Freud terjadi apabila seseorang bereaksi secara tidak rasional atas satu pengalaman yang amat emosional dan memalukan (Franz Magnis Susano,2006:85, Yustinus, 2006:316).

Dalam teori personaliti Freud, dijelaskan bahawa, personaliti manusia berasaskan kepada id, ego dan superego. Sistem ini menurut Najati, ada persamaan dengan dengan kefahaman Islam tentang jenis-jenis al-nafs seperti al-nafs lawwamah, al-nafs a-ammarah bi al-su' dan al-nafs al mutmainah (dalam Amaludin Ab. Rahman, 2008: 78). Hal ini juga disokong oleh Mohd Ismail Mustari (2007:11) yang berpendapat bahawa teori Freud yang mempunyai banyak persamaan dengan ajaran Islam iaitu tentang aspek manusia yang selalu kalah dengan desakan nafsu (id) yang kebanyakannya membawa kepada maksiat kerana bertentangan dengan ajaran syariat (superego) dan cara mengatasinya adalah dengan menggunakan akal (ego). Maka, dalam kajian ini memperlihatkan aspek emosi dalaman watak dengan dibantu oleh struktur pemikiran minda manusia menurut Freud.

Namun, pada peringkat permulaan didera, dalam menerangkan aspek neurosis dalam diri Yang, reaksi Yang ialah mahu menangis (id). Tambahan lagi hatinya amat sakit (id) kerana geram didera. Malahan fizikal Yang seperti anggota kepala, juga sakit kerana terkena ketukan pembaris, tetapi Yang masih mampu 
menahan kesakitan. Yang tahu, kalau dia menangis, mereka akan berasa seronok. Dia tidak mahu menunjukkan kelemahan (superego). Helah bela diri yang dipilih Yang ialah dia harus menahan air matanya supaya tidak gugur di pipi (ego).

Akhirnya, konflik antara id dan ego yang selalu mengganggu Yang, menyebabkan akhirnya Yang telah mengikut kata id iaitu bertindak melawan. Emosi yang dilepaskan oleh Yang dikenali sebagai neurosis dan Yang telah melakukan neurosis dalam bentuk helah bela diri agresi iaitu usaha untuk merealisasikan kekecewaan yang dialami. Perlakuan itu melibatkan tindakan fizikal yang memberi kesan negatif kepada diri sendiri dan orang lain (Shahbuddin Hashim, Mahani Razali dan Ramlah Jantan, 2004:101).

Dalam hal ini Yang telah bertindak balas dengan membaling semula benda ke arah rakan-rakannya yang telah melemparinya dengan benda-benda. Jika terdapat rakan-rakan yang telah mencubit, memukul dan mencucuknya, Yang turut membalas dengan perbuatan yang sama. Namun, kadang-kadang Yang dicubit, dipukul dan dicucuk oleh ramai orang. Hal ini menyebabkan Yang Zaiton telah meludah mereka. Walau bagaimanapun, terdapat satu perkara yang Yang Zaiton tidak dapat membalas iaitu ejekan dan hinaan rakan-rakan yang memanggilnya dengan gelaran "Yang Cina". Natijahnya, emosi takut disakiti yang terlalu menekan dirinya menyebabkan berlaku neurosis yang terbaru. Komplikasi neurosis ini ditutup dengan helah bela diri seterusnya yang dilakukan oleh Yang iaitu bersikap rasionalisasi bagi melindungi egonya. Yang telah mengambil keputusan untuk tidak ke sekolah lagi (id) kerana tidak mahu disakiti. Jelas dilihat ego tidak dapat mengawal id kerana desakan id yang terlalu takut untuk disakiti. Hal ini boleh dilihat menerusi petikan yang berikut:

Sedih Yang begitu mendera. Yang mahu menangis. Hatinya amat sakit. Tubuh badan serta kepala juga sakit terkena ketukan pembaris, tetapi ditahan sekeras hati. Yang tahu, kalau dia menangis, mereka akan seronok. Dia tidak mahu menunjukkan kelemahan. Yang telan air matanya supaya tidak gugur di pipi.

(Zaharah Nawawi ,2004:64)

Badannya juga calar dan lebam di sana sini. Pagi besok dia tidak mahu ke sekolah. Biar dia tidak pandai menulis dan membaca, tidak apa, asalkan hati dan diri tidak disakiti.

(Zaharah Nawawi ,2004:68)

Korelatif objektif penderaan dikembangkan dengan baik oleh ZN sejajar dengan perkembangan watak utama iaitu Yang Zaiton yang telah meningkat remaja iaitu berumur 12 tahun. Evolusi emosi daripada peringkat praestetik berkembang kepada peringkat pengkonkritan estetik. Evolusi emosi Rasa dahsyat dalam novel HST daripada penderaan kanak-kanak berkembang kepada penderaan pencabulan seks. Bagaikan jatuh ditimpa tangga, Yang Zaiton yang telah tinggal bersama-sama dengan Timah sepupu Maimon telah cuba dicabuli oleh Mokhtar iaitu anak sulung Timah yang berusia tujuh belas tahun. Yang Zaiton pada masa itu sedang mandi di perigi telah diintip oleh Mokhtar. Mokhtar telah merentap Yang dari arah belakang dengan rentapan yang kuat sehingga menyebabkan Yang tiada keseimbangan diri dan jatuh ke dalam perigi. Namun, tenaga jantan Mokhtar amat kuat dan berjaya menarik Yang keluar dari perigi. Yang berasa terancam kerana harga dirinya makin hampir cuba dinodai oleh Mokhtar.

Akhirnya, senjata terakhir Yang ialah pelakuan menjerit dengan sekuat-kuat hati dan bertalu-talu supaya dapat didengari oleh orang lain. Mokhtar pula tanpa melengahkan masa telah menutup mulut Yang dengan menggunakan tangannya. Nasib Yang baik kerana, Halimah adik kepada Mokhtar telah balik dari kedai dan telah mendengar jeritan Yang. Halimah telah menggunakan kayu dan menghentakkan kayu tersebut ke kepala Mokhtar. Mokhtar kesakitan dan berlari pantas meninggalkan tempat kejadian. Akhirnya Yang terselamat daripada dicabul. Namun, penderaan emosi akibat peristiwa ini telah menyebabkan Yang 
sentiasa berada dalam ketakutan. Yang menjadi takut kepada orang lebih-lebih lagi jika mendengar suara lelaki. Keparahan emosi Yang boleh dilihat menerusi petikan:

Haron baru pulang dari Batu Pahat. Dia melihat Yang berdiri termenung di tingkap. Dia menyapa. "Yang." Suaranya besar dan lembut. Yang terkejut. Dia menjerit sekuat hati bagaikan kena rasuk. Dia benar-benar dihantui Rasa takut. Peristiwa di pinggir sumur di rumah Timah menjadi igauan negeri yang sukar dipadamkan daripada sanubari. Maimon sedang berkira-kira hendak menyambut kepulangan Haron ketika itu. Tindakan Yang bukan sekadar tidak diduga, malah sungguh memeranjatkan. Yang melompat dari tempat berdiri, berlari kencang menuju bilik, menerjah daun pintu, menutup dengan keras dan menolak selak, berdetak nyaring menyentap perasaan.

(Zaharah Nawawi, 2004:214)

Dapatan kajian Urus Setia Jawatankuasa Bertindak Peringkat Kebangsaan Laporan Masyarakat Penan (2008), mendapati, kanak-kanak perempuan yang mengalami penderaan seksual menyebabkan mangsa berada dalam keadaan tertekan dan takut peristiwa yang sama akan berulang sehingga menimbulkan penderaan emosi kepada mangsa. Indikator tingkah laku yang ditunjukkan oleh mangsa ialah mudah meradang, ponteng sekolah, sukar memberikan tumpuan dalam pelajaran, dan kemurungan.

Maka, signifikan kajian ini menunjukkan persamaan dengan sikap Yang iaitu menjadi murung. Yang menjadi murung dan takut kepada orang lelaki. Hal ini menyebabkan orang yang rapat disekeliling Yang menjadi bimbang dengan perubahan tingkah laku Yang. Semestinya, korelatif objektif penderaan yang dihidupkan oleh pengarang mampu mengembang emosi tetap pembaca ke arah emosi yang cuba menghayati dan tenggelam dalam karya. Emosi tetap pembaca akan berubah menjadi emosi estetik dan pembaca semakin bersatu dengan karya. Emosi dalam karya pula dikembangkan dengan kekuatan teknik penulisan pengarang yang diasosiasikan antara unsur dalam karya, antara unsur di luar karya dan juga antara karya dengan karya yang lain. Ketiga-tiga pola ini berlaku dalam imaginasi pembaca dan dikenali sebagai imaginasi dialogik yang dikenali sebagai estetik intertekstual (Sohaimi Abd Aziz, 1998:104).

Dalam menanggapi korelatif objektif penderaan emosi akibat percubaan penderaan seksual ini, dapat dilihat Yang telah mengalami peristiwa trauma. Peristiwa ini telah menghantui diri Yang sehingga menyebabkan Yang mengalami neurosis. Yang telah melepaskan ketakutannya dengan menjerit sekuatkuat hati bagaikan dirasuk dan hal ini sinonim dengan fenomena neurosis yang tidak terkawal oleh ego yang menyebabkan berlakunya perlakuan mekanisme helah bela diri iaitu penyangkalan. Penyangkalan merupakan penafian atau penolakan akan adanya realiti. Penyangkalan dilakukan secara sedar atau tidak sedar. Sesuatu peristiwa traumatik yang terlalu hebat untuk diterima oleh seseorang individu pada ketika itu terpaksa dinafikan bagi mengawal kestabilan emosi dan fikiran seseorang itu. Yang bukan sahaja menjerit, malah Yang telah melompat dan berlari kencang ke bilk serta menutup pintu bilik dengan kuat.

Fenomena ini jelas menunjukkan keadaan id Yang Zaiton yang tidak terkawal sehingga ego tidak lagi dapat mengawal tindakan id. Sudah tentu, pada masa itu yang ada dalam fikiran Yang Zaiton ialah dia ingin melarikan diri kerana terdengar suara lelaki. Tindakan Yang Zaiton telah tidak mengikuti norma superego. Sepatutnya, Yang Zaiton dapat membezakan antara suara lelaki yang cuba mencabulnya dan suara abang iparnya sendiri. Penyakit trauma telah menyebabkan Yang Zaiton telah kehilangan kewarasan dalam fikiran untuk membezakan suara lelaki. Pemikiran bawah sedar Yang Zaiton telah menguasai fikirannya sehingga mengakibatkan Yang Zaiton seperti orang yang telah kehilangan kewarasan.

ZN tidak menamatkan korelatif objektif Emosi takut iaitu penderaan hanya setakat itu sahaja. Malah, ZN telah mengembangkan korelatif objektif penderaan kepada penderaan fizikal dalam alam rumah tangga. Namun, perkara yang lebih penting ialah penderaan fizikal yang terjadi telah menyebabkan penderaan emosi yang berpanjangan dan perasaan kelukaan yang bertahun-tahun lamanya. $\mathrm{ZN}$ telah menambahkan tekanan emosi pembaca dengan mengisahkan kehidupan berumah tangga Yang dengan suaminya yang ketiga dalam pengisahan yang penuh dengan tragedi dramatik. 
Yang Zaiton dicemburi oleh suaminya Mail kerana Mail beranggapan Yang Zaiton telah berlaku curang dengan anak sulungnya Kahar. Namun, sikap cemburu Mail sama sekali tidak berasas kerana Mail melakukan hukuman kepada Yang secara membuta tuli tanpa penyiasatan. Akibatnya, Yang dibelasah oleh Mail dengan sepenuh tenaga yang ada pada Mail. Mail telah mencekik leher Yang, dan menendang serta memukul Yang secara berterusan. Peristiwa kekejaman Mail kepada Yang boleh dilihat menerusi petikan yang berikut:

Apabila dia menghampiri Yang, tangan lelaki yang seperti kehilangan akal itu mencekik leher isteri. Maimon menjerit. "Jangan Mail, jangan!’Mail tidak peduli. "Lepas Mail! Jangan cekik dia! Dia tidak bersalah!". Mail tidak mendengar rayuan Maimon. Dia masih ganas mencari sasaran di leher Yang yang meronta-ronta cuba melepaskan diri sementara Kahar menarik tangan Mail sekuat tenaga...

(Zaharah Nawawi, 2004:353)

... rambut Yang ditarik dan diganyangnya sekehendak hati... Ketika Yang cuba meninggalkan tempatnya terduduk tadi, Mail menerajang dari belakang. Yang tertiarap di lantai. Matanya berpinarpinar. Beberapa saat segalanya bertukar menjadi gelap. Dia tidak tahu apa seterusnya berlaku.

(Zaharah Nawawi, 2004:386)

Dalam peristiwa penderaan ini, menunjukkan sikap Mail yang bersikap seperti orang yang tidak siuman dan tidak beragama Islam. Sedangkan dalam Islam sendiri terdapat banyak ayat al-Quran dan hadishadis Nabi yang memuliakan kaum wanita lebih-lebih lagi seorang isteri yang menjadi ibu rumah tangga dan ibu kepada zuriat keturunan suami. Sebagaimana dalam hadis nabi diriwayatkan ada seorang lelaki yang telah bertanya kepada rasulullah tentang insan yang paling berhak untuk berlaku baik sebagaimana dalam petikan di bawah:

"Wahai Rasulullah, siapa orang yang paling berhak bagi aku untuk berlaku bajik kepadanya?" Nabi menjawab, "Ibumu." Orang itu bertanya lagi, "Kemudian setelah dia siapa?" Nabi menjawab, "Ibumu." Orang itu bertanya lagi, "Kemudian setelah dia siapa?" Nabi menjawab, "Ibumu." Orang itu bertanya lagi, "Kemudian setelah dia siapa?" Nabi menjawab, "Ayahmu."

(HR. Bukhari, Kitab al-Adab no. 5971 juga Muslim, Kitab al-Birr wa ash-Shilah no. 2548 dalam Salinah Jaafar \& Tengku Intan Marlina Tengku Mohd Ali, 2010)

Begitu besarnya darjat seorang wanita, iaitu tiga kali lebih besar daripada seorang bapa. Namun, Mail tidak mengetahui hal-hal keislaman seperti ini. Rentetan daripada peristiwa penderaan yang dilakukan Mail, natijahnya, Yang telah keguguran anak yang ketiga kerana ketika itu Yang sedang mengandung. Betapa dahsyatnya penderaan fizikal yang terjadi sehingga mengakibatkan keguguran. Emosi pembaca seperti direntap dan bagi khalayak pembaca wanita, sudah pasti pengalaman keguguran mereka akan bersatu dengan pengalaman Yang Zaiton dan mereka juga akan berasa kesakitan.

Bagi pembaca wanita yang mengalami nasib yang sama seperti Yang sudah pasti akan menggabungkan pengalaman mereka dan beremosi seperti Yang. Hal ini bertepatan dengan hasil kajian dalam Emotional Impact of Loss Narratives: Event Severity and Narrative Perspectives oleh Habermas dan Diel (2010). Mereka telah memetik pendapat penulis seperti Scheff (1979), Oatley (1992), dan Tan (1996) tentang emosi dalam penceritaan. Menurut mereka, emosi dalam penceritaan ialah emosi estetik yang bertindak balas terhadap cerita sebagai suatu artifak. Estetik ini dihasilkan daripada keseronokan dan kenikmatan estetik bersama-sama dengan keadaan ketegangan dan kejutan dalam sesebuah penceritaan. 
Situasi ini menimbulkan ketegangan emosi dalam jiwa pembaca dan pembaca menghubungkaitkan memori peribadi pembaca yang ada dalam suatu penceritaan. Maka, evolusi emosi akan sentiasa berkembang dalam novel ZN.

Karakter Yang Zaiton yang tertekan kerana didera secara fizikal telah memberikan perubahan besar kepada hidupnya. Yang Zaiton telah mengikut tindakan id, iaitu pergi meninggalkan suami serta anakanaknya. Malah Yang dengan beraninya telah menjawab pertanyaan suaminya Mail dengan suara yang nyaring. Id yang telah menguasai fikiran Yang telah menyebabkan Yang telah mengatakan Mail bukan lagi suaminya lagi. Hal ini terjadi kerana ego Yang tidak dapat mengawal id yang terlalu menderita kesakitan dari segi fizikal dan emosi. Akibatnya, Yang dengan berani telah melanggar norma superego seorang wanita iaitu harus mentaati suami dan jangan sesekali menderhaka kepada suami. Bagi Yang kehidupan di rumah suaminya bagaikan kehidupan di neraka jahanam. Betapa seksanya kehidupan Yang kerana disinonimkan dengan neraka. Sebagai orang Islam, neraka ialah tempat pembalasan perbuatan jahat manusia di dunia. Neraka ialah suatu tempat tinggal yang abadi bagi manusia yang melampau batas dalam kehidupan mereka. Mereka akan tinggal di sana dalam tempoh yang lama. Dalam al-Quran Surah an-Naba ayat ke 21 hingga 30, Allah berfirman:

Sungguh (neraka) jahanam itu (sebagai) tempat pengintai (bagi orang yang mengawasi isi neraka), menjadi tempat kembali bagi orang-orang yang melampaui batas. Mereka tinggal di sana dalam tempoh masa yang lama. Mereka tidak merasakan kesejukan di dalamnya dan tidak (pula mendapat) minuman, selain air yang mendidih dan nanah, sebagai pembalasan yang setimpal.

Dalam ayat al-Quran di atas menunjukkan, neraka sebagai suatu tempat yang amat dahsyat kerana tiada minuman melainkan air yang mendidih dan nanah. Air yang mendidih tidak boleh diminum kerana terlalu panas dan boleh mengakibatkan kelecuran di dalam mulut. Air yang bernanah pula mengandungi kuman dan bakteria serta berbau amat busuk dan hanyir. Adakah Yang Zaiton bermaksud demikian ketika mengatakan kehidupannya bersama-sama dengan suaminya seperti hidup di dalam neraka? Sememangnya, penderitaan Yang Zaiton tidak tertanggung sehingga terpaksa menyamakan kehidupannya sama seperti di dalam neraka.

Mail telah cuba menahan Yang daripada berlalu pergi meninggalkan rumah tangga mereka. Namun, tindakan Yang amat memeranjatkan. Akibat desakan id, menyebabkan Yang sanggup menghempaskan dirinya ke tanah. Sedangkan pada masa itu, Yang sedang mengandung. Bahkan Yang tidak lagi ambil peduli jika didapati kandungannya gugur. Situasi ini jelas menunjukkan id yang tidak terkawal dengan ego, hingga melanggar norma superego. Majoriti wanita bersikap sayang akan kandungannya dan sentiasa menjaga kandungannya dengan baik. Sebaliknya, Yang pula bersikap seperti pembunuh kepada janinnya sendiri kerana sengaja menghempaskan diri ke tanah. Dorongan daripada id menyebabkan Yang Zaiton tidak sedar akan perlakuannya yang telah membahayakan dirinya. Sememangnya id sentiasa bertindak secara tidak rasional. Akhirnya, watak akan mengalami komplikasi neurosis.

Komplikasi neurosis Yang Zaiton terus berkembang. Hal ini disebabkan, Mail telah mengugut Yang Zaiton untuk menceraikannya jika Yang Zaiton tetap berdegil untuk keluar dari rumah. Bertentangan dengan diri Yang, apabila mendengar perkataan cerai, bagi dirinya ialah kebahagiaan, kebebasan dan tidak lagi terpenjara dalam kehidupan yang penuh seksa dan penghinaan. Perasaan kebebasan yang Yang Zaiton alami telah menyebabkan Yang Zaiton berlari pantas meninggalkan rumahnya. Peristiwa ini jelas menunjukkan, sikap helah bela diri Yang iaitu pembentukan reaksi. Pembentukan reaksi ialah suatu mekanisme tindakan yang bertentangan dengan bentuk ancaman itu. Sewajarnya, Yang Zaiton akan menangis kerana diceraikan tetapi Yang Zaiton berasa gembira dan berlari-lari.

Evolusi emosi kejiwaan dalam peringkat ini memperlhatkan watak protagonis sentiasa menunjukkan dalam keadaan berneurosis dahulu. Selepas itu, protagonis akan melakukan helah bela diri dan ZN akan merakam struktur pemikiran minda protagonis yang tidak mengalami keseimbangan (id, ego dan superego) 
yang menyebabkan konflik terjadi. Sorotan justifikasi pengadilan estetik Emosi takut dalam karya $H S T$ terlalu pahit untuk ditelan kerana ZN telah mewarnakan kehidupan Yang Zaiton penuh dengan kehitaman penderitaan dan seksaan emosi yang memerangkap emosi pembaca dalam menghayati karya.

Penghitaman latar masyarakat setempat Yang Zaiton telah mengangkat korelatif objektif penderaan yang dirakamkan oleh ZN. Latar masyarakat setempat yang masih terkongkong dari segi pemikiran dalam status anak angkat, lebih-lebih lagi anak angkat berketurunan Cina. Bagi mereka, keturunan Cina ialah keturunan pengotor dan jijik kerana kehidupan mereka sinonim dengan dua najis mughallazah dalam kehidupan orang Islam iaitu anjing dan babi.

Latar masyarakat HST masih lagi ortodoks dengan fenomena gelaran janda. Bagi mereka 'janda' ialah suatu yang negatif dan disebabkan kesialan inilah golongan yang memegang status janda sering menjadi sasaran fitnah (Abdul Aziz Salim Basyarahil \& Mohd Fauzil Adhim, 1999:206). Malah pewarnaan watak Yang Zaiton yang berumah tangga juga sering menjadi fitnah orang kampung. Hal ini terjadi kerana Yang Zaiton hanyalah seorang anak angkat yang berketurunan Cina.

Akibatnya, Emosi takut dalam karya telah mengesan jiwa Yang Zaiton yang telah mengalami gangguan kejiwaan seperti peristiwa trauma. Kehidupan traumatik Yang Zaiton bermula sejak zaman kanak-kanak lagi. Sejak berumur lima tahun Yang Zaiton telah kehilangan insan yang disayanginya iaitu Nek Yah. Kajian menunjukkan kanak-kanak yang kematian ibu bapa mempunyai risiko yang tinggi menghadapi masalah emosi yang berpanjangan. Reaksi hiba adalah reaksi yang akan dihadapi mereka seperti sedih, rindu dan sebagainya. Mereka juga menunjukkan kelakuan yang bermasalah seperti bimbang, kebergantungan, anti sosial dan tingkah laku agresif.

Signifikan kajian ini bertepatan dengan cara-cara ZN mengolah watak Yang Zaiton yang mengalami peristiwa trauma. Peristiwa trauma terjadi semula kepada Yang Zaiton semasa berumur 12 tahun kerana mengalami gangguan penderaan pencabulan seksual. Akhirnya, Yang Zaiton berasa trauma untuk berkahwin lagi kerana penderaan fizikal, psikologi dan emosi oleh bekas suaminya Mail. Depresi juga merupakan ironis kegawatan kehidupan Yang Zaiton. Depresi bukan sekadar suatu keadaan sedih sahaja tetapi boleh menyebabkan terganggunya aktiviti sosial sehari-hari. Yang Zaiton mengalami depresi sewaktu didera oleh kawan-kawan, penderaan akibat cuba dicabul dan penderaan dalam perkahwinan. Keadaan depresi ini telah menyebabkan Yang Zaiton selalu berhalusinasi. Aspek berhalusinasi boleh dilihat dalam petikan:

"Mak." Yang ternampak lambaian Nek Yah. Yang bangun. Dia melangkah mengikut Nek Yah yang terus-terusan menggamit. Nek Yah berjalan balik ke rumah. Kaki Yang pantas mengikut. Tiba-tiba Nek Yah hilang daripada pandangan. Yang tercari-cari. Matanya melilau memandang sekitar. Yang sedar, dia kini berdiri menghadap batu nisan di pusara arwah Nek Yah.

(Zaharah Nawawi, 2004:189)

Dalam petikan, Yang telah berhalusinasi ternampak Nek Yah sedang melambai-lambaikan tangan ke arahnya. Namun, konteks sebenarnya, Yang sedang berada di kawasan perkuburan Nek Yah. Yang mengalami kejadian ini kerana, mengalami depresi dalam kehidupan sehingga menyebabkan Yang seperti ternampakkan Nek Yah yang selama ini merupakan insan yang amat rapat dan sentiasa menyayanginya. Daripada petikan, jelas menunjukkan perasaan neurosis yang dahsyat telah mengakibatkan depresi sehingga boleh membawa kepada keadaan berhalusinasi. Malah, terdapat juga fenomena id Yang yang ingin bersama-sama dengan Nek Yah di alam fana. Yang menangis tidak berhenti di sisi Maimon dengan mengatakan bahawa dia hendak menuruti ibunya ke alam baqa. Hal ini boleh dilihat menerusi petikan:

"Yang hendak ikut mak.”Yang ulang permintaannya sambil mendongak memandang Maimon.

"Tidak boleh. Tuhan belum ambil nyawa Yang. Yang tidak boleh mati macam emak. Nanti masuk neraka. Duduk dalam neraka lebih dahsyat daripada malu di dunia.

(Zaharah Nawawi, 2004:166) 
Merujuk petikan, peristiwa ini terjadi kerana konflik emosi dalaman yang tidak tertahan-tahan lagi sehingga mengakibatkan Yang seperti mahu mati seperti Nenek Yah. Bagi Yang mungkin mati itu lebih baik daripada terus hidup menderita, malu dan dihina.

Penggabungan TRF dan Psikoanalisis Freud telah menghasilkan suatu analisis evolusi emosi yang memahami jiwa dan emosi dalam karya dalam mengembangkan Emosi takut dalam karya. Lebih-lebih lagi TRF amat mementingkan proses emosi yang berkembang dan merangsang emosi dalam karya dengan melalui tiga peringkat yang mengevolusikan emosi pembaca, dan emosi dalam karya. Tidak dinafikan juga emosi pengarang juga terdapat dalam analisis, lebih-lebih lagi dalam peringkat praestetik yang memerlukan pembacaan tentang sosiologi pengarang untuk memberikan gambaran emosi yang dirakamkan dalam karya.

Pelengkapnya, teori Freud yang mampu untuk merungkaikan aspek watak dengan jiwanya yang berevolusi antara emosi id, emosi ego dan emosi superego. Izharnya, laluan evolusi emosi Emosi takut dapat membantu pembaca untuk mencapai kenikmatan emosi dalam karya seterusnya dapat mengamati cara-cara emosi Emosi takut dalam karya yang merupakan suatu fenomena kepada karya-karya ZN secara khususnya dan karya pengarang wanita secara amnya.

\section{KESIMPULAN}

Rumusannya, Emosi takut yang dikemukakan oleh ZN dapat dirasa oleh emosi pembaca. Pembaca berasa evolusi emosi takut yang berakhir dengan kesedihan apabila membaca peristiwa yang telah diadun oleh ZN dengan korelatif objektif terpilih. Dalam dunia nyata, korelatif objektif emosi takut dalam novel HST iaitu penderaan fizikal, mental dan emosi sememangnya semakin menjadi dari hari ke hari. Emosi takut tersebut dapat dilihat menerusi laporan di media cetak sehari-hari. Wanita Melayu yang menghadapi emosi takut akan mempunyai emosi tenaga akhirnya, dalam melawan emosi takut yang terdapat dalam dirinya. Sebagaimana tajuk novel iaitu Hujan Sudah Teduh yang merupakan metafora kepada emosi wanita Melayu, walaupun mulanya digambarkan mempunyai pelbagai emosi yang negatif, namun akhirnya kesemua emosi itu dapat dileraikan dan diatasi. Dalam kamus wanita Melayu, tiada perkara yang tidak dapat diselesaikan kerana, walaupun rintangan yang melanda akhirnya rintangan itu dapat diatasi sebagaimana tajuk walau bagaimana hujan turun dengan lebatnya serta diiringi kilat dan petir yang memancar namun, akhirnya akan berhenti juga.

\section{RUJUKAN}

Abdul Aziz Salim Basyarahil \& Mohammad Fauzil Adhim. (1999). Janda. Jakarta: Gema Insani.

Adi W.Gunawan. (2007). Kesalahan Fatal dalam Mengejar Impian 2. Jakarta: PT.Gramedia Pustaka Utama.

Afifi Ahmad. (2005). Membina Impian: Daripada Angan-Angan Menjadi Cita-Cita. Bentong: PTS Millenia Sdn. Bhd.

Amaludin Ab. Rahman. (2008). Perkhidmatan Kaunseling. Kuala Lumpur: Utusan Publications \& Distributors.

Amir Awang. (1987). Teori dan Amalan Psikoterapi. Pulau Pinang: Universiti Sains Malaysia.

Amida Abdulhamid. (2004). Persoalan Dendam dalam Sastera Melayu. Kuala Lumpur: Penerbitan Universiti Malaya.

Amida Abdulhamid. (2008). Rangkaian Falsafah dalam Analisis Sastera. Tanjong Malim:Universiti Pendidikan Sultan Idris.

Cicchetti, D. \& Toth, S. L. (1995). A developmental psychopathology perspective on child abuse and neglect. Journal of the American Academy of Child and Adolescent Psychiatry, 34, 541-565.

Grobe, M. (2001). Citizen Brand. (terjemahan Sri Isnani Husnayati, S.E) Jakarta: Erlangga. 
Habermas, T., Meier, M., \& Barbara Mukhtar. (2009). Are specific emotions narrated differently. Emotion, 9(6) 751762. doi: $10.1037 / \mathrm{a} 0018002$.

Habermas,T., \& Diel,V. (2010). The emotional impact or loss narratives: Event severity and narrative perspectives. Emotion 10(3), 312-323. doi:10.1037/a0018001

Habibah Elias \& Noran Fauziah Yaakub. (1997). Psikologi Personaliti. Kuala Lumpur: Dewan Bahasa dan Pustaka.

Hergenhahn, B. R., \& Olson, M.H. (2003). An Introduction to Theories of personality. New Jersey: Pearson Education.

Jadunath Sinha. (1986). Indian Psychology, 2. Calcutta: Motilal Banarsidass Publications.

Jamilah Samian. (2011). 'Mak, saya takut!'. Diperoleh daripada: www.iluvislam.com/keluarga/ibu-bapa/4876-qmaksaya-takut.html

(Jawatankuasa Bertindak Peringkat Kebangsaan Bagi Menyiasat Dakwaan Penderaan Seksual Terhadap Wanita Kaum Penan, 2008) Jawatankuasa Bertindak Peringkat Kebangsaan Bagi Menyiasat Dakwaan Penderaan Seksual Terhadap Wanita Kaum Penan. (2008). Laporan Jawatankuasa Bertindak Peringkat Kebangsaan Bagi Menyiasat Dakwaan Penderaan Seksual Terhadap Wanita Kaum Penan. Retrieved from https://hornbillunleashed.files.wordpress.com/2009/09/penan-ir.pdf

Kasmini Kassim. (1998). Penderaan emosi kanak-kanak: Trauma terselindung. Diperoleh daripada laman web: http://www.ukm.my/penerbit/emosi.pdf.

Kuppusamy Bangalore. (2008). Advanced Educational Psychology. New Delhi: Sterling Publissher

Mana Sikana (peny). (1997). Teori Sastera dan Budaya dalam Kajian Akademik. Universiti Kebangsaan Malaysia, Bangi.

Mohd Ismail Mustari. (2007). Menjadi Belia Cemerlang. Kuala Lumpur: PTS Professional Publishing Sdn. Bhd.

Mudji Sutrisno, Fitzgerald K.Sitorus, Hnery Stephen, Bagus Taufik Dwiko NP, Inigo ARIO Soembogo, LeoParamadita, Fristian Yulianto, Abdul Hakim.,...Tan, Shot Yen. (2005). Teks-Teks Kunci Estetika: Filsafat Seni. Yogyakarta: Galangpress.

Nordiana Hamzah. (2014). Evolusi Emosi Novel Zaharah Nawawi. Tesis PHD, Universiti Pendidikan Sultan Idris (tidak diterbitkan).

O’Hagan, K. (2006). Identyfying Emotional and Psychological Abuse. Berkshire: McGraw Hill Education.

Peter, M. \& Johari, H. (2006). The Yoga of The Nine Emotions: The Tantric Practice Of Rasa Sadhana. Rochester: Inner Traditions Bear \&Co.

Rahil Mahyuddin, Habibah Elias \& Mariah Chong Abdullah. (2004). Psikologi Kanak-Kanak dan Remaja. Serdang: Universiti Putra Malaysia.

Salinah Jaafar, \& Tengku Intan Marlina Tengku Mohd Ali. (2010). Ikon wanita islam antara Malaysia dan Indonesia novel: Analisis tanda dalam perkataan. Jurnal Aswara, 5(2), 1-11. Retrieved from http://repository.um.edu.my/17742/1/Jurnal Aswara 2011 .pdf

Shahabudin Hashim, Mahani Razali \& Ramlah Jantan. (2004). Psikologi Pendidikan. Kuala Lumpur: PTS Professional Publishing Sdn Bhd.

Sohaimi Abdul Aziz. (1995). Rasa Fenomenologi sebagai satu teori pengalaman estetik: Satu kajian karya-karya A. Samad Said. (Tesis PHD yang tidak diterbitkan). Universiti Sains Malaysia, Pulau Pinang.

Sohaimi Abdul Aziz. (1998). Rasa Fenomenologi: Penerapan Terhadap Karya A. Samad Said. Kuala Lumpur: Dewan Bahasa dan Pustaka.

Sohaimi Abdul Aziz. (1998). Membentuk Kecerdasan Emosi Kanak-Kanak. Pulau Pinang: Penerbit Universiti Sains Malaysia.

Suppiah Nachiappan, Ramlah Jantan \& Abdul Aziz Abdul Shukur. (2008). Psikologi Pendidikan. Shah Alam: Oxford Fajar Sdn. Bhd.

Timo, M. (2010). The self as object in modernist Fiction: James, Joyce Hemingway. Germany:Konigshausen \& Neumann.

Thomas, R. M. (1996). Comparing Theories of Child Development. California: Brooks/Cole Publishing Company. Yustinus Semiun. (2006). Kesihatan Mental 1. Yogyakarta: Penerbit Kanisius.

Yustinus Semiun. (2010). Teori kepribadian dan terapi psikoanalitik Freud. Yogyakarta: Penerbit Kanisius.

Zaharah Nawawi. (2004). Hujan sudah teduh. Kuala Lumpur: Dewan Bahasa dan Pustaka. 